The fact that diacetyl has not been found in sugar fermentations by yeast can be ascribed to an immediate reduction of the primarily produced diacetyl. In order to lessen the possibility of such reduction, pyruvic acid was used as substrate. With dry brewer's yeast, formademonstrated by the analytical method of Langenbeck, Wrede and Bchlockermanns.

These experimental results support Martius' hypothesis that dehydrogenation of pyruvic acid is an essential condition for the forma. tion of the aroma substances, and that in fermentations this process through the stages diacetyl $\rightarrow$ acetylmethylcarbinol $\rightarrow 2,3$-butylene glycol. They likewise support Myrbäck's view that the disulphide form of diphosphothiamine takes an active part in the dehydrogenation af pyruvic acid.

Department of Biochemistry, HEIKKI SUOMALA LNEN.

Alcohol Research Laboratory, Helsinki.

1. physiol. Chem., 279, 96 (1943).

- Nature, 140, 25 (1937). Enzymolog., 4, 65 (1937).

Svensk. Kem. Tidskr., 56, 296, 400 (1944); 57, 72, 124 (1945)

'Z. phusiol. Chem., 227, 26 (1934).

\section{Influence of Starch in Media Used for the Detection of Heated Bacterial Spores}

DURING investigations of the heat resistance of the spores of several Australian strains of Clostridium botulinum, it was found that various Anstralian strains of Clostridium botulinum, it was found that various ment, even though each medium indicated similar numbers of viable gpores in the unheated suspension. An attempt was made, therefore, to prepare a medium which would be reliable for the detection of spores surviving heat treatment. It has now been shown that the of colonies which develop from an inoculum of heated spores. Several of colonies which develop from an inoculum of heated spores. Several media suitable for the growth of $C l$. botulinum. The influence of media suitable for the growth of $\mathrm{Cl}$. botulinum. The influence of thioglycollate agar ${ }^{1}$ is shown in the accompanying graph.

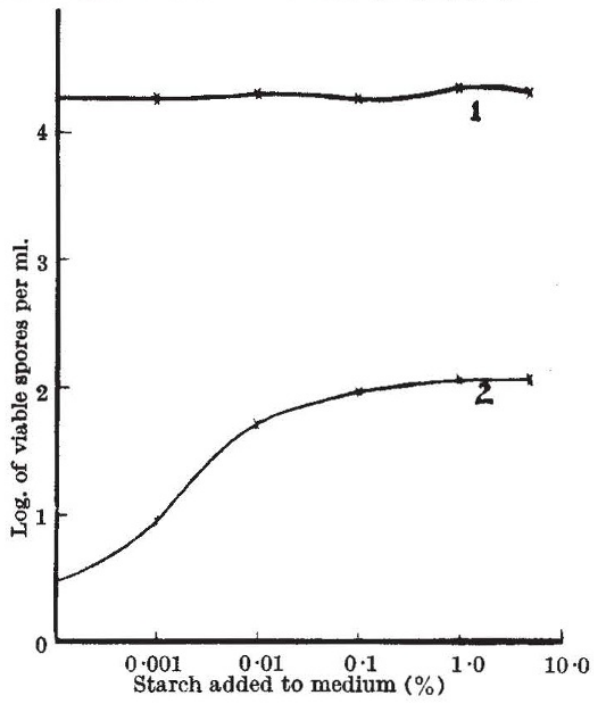

Cl. botulinum SPORES HEATED AT $100^{\circ} \mathrm{C}$. IN $M / 15$ PHOSPHATE

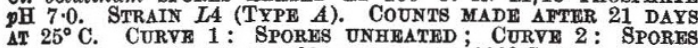
HEATTED FOR 60 MINUTES $\triangle T$ T $100^{\circ} \mathrm{C}$.

The estimates of unheated spores are virtually independent of the smount of starch in the medium, whereas the numbers of heated gpores producing colonies are significantly increased by additions of tarch up to approximately 0.1 per cent. The magnitude of the regponse to starch increases with the time of heating. The observed differences between media are not due to variations in the amount of hesting as all comparisons are based on inoculations from the contents of one tube of heated spore suspension.

The action of starch is believed to be unique for the following reasons. No other polysaccharide tested shows any comparable effect. Th sctivity of starch is unaffected by exhaustive extraction with 95 per cent ethanol, 85 per cent methanol, cold water, diethyl ether, or carbon tetrachloride, and the extracts are inactive. Repeated precipitation with alcohol causes no loss of activity. Maltose, glucose and glucose-1phosphate are all without effect, and starch is rendered inactive by hydrolysis with mineral acld and also by crude $\alpha$ and $\beta$ amylase preparations. Two samples of glycogen failed to show the properties of the starches, whereas a sample of synthetic starch prepared by C. 8 . Hanes was at least as active as the natural starches (see table). C. . Hanes was at least as active as the natural starches (see table). been tested, and the butanol-precipitated fraction found to be four Cl. botulinum SPORzS HEATED AT $100^{\circ} \mathrm{C}$. in $M / 15$ PHOSPHATE $p$ H $7 \cdot 0$.
Figures represent populations $/ \mathrm{ml}$. after incubation for 21 days at $25^{\circ} \mathrm{C}$.

\begin{tabular}{|c|c|c|c|c|}
\hline Medium & \multicolumn{2}{|c|}{$\begin{array}{c}\text { Strain } L 4(\text { Type } A) \\
0 \text { min. }\end{array}$} & \multicolumn{2}{|c|}{$\begin{array}{l}\text { Strain } L 12 \text { (Type } B) \\
0 \text { min. } \\
120 \text { min. }\end{array}$} \\
\hline \multirow{6}{*}{$\begin{array}{l}\text { Pork infusion thio- } \\
\text { glycollate agar } p \mathrm{H} 7 \cdot 3 \\
+0 \cdot 01 \% \text { soluble } \\
\text { starch } \\
+0 \cdot 1 \% \text { soluble } \\
\text { starch } \\
+0 \cdot 01 \% \text { syn- } \\
\text { thetic starch } \\
+0 \cdot 1 \% \text { syn- } \\
\text { thetic starch }\end{array}$} & 12,000 & 20 & 21,000 & 15 \\
\hline & 15,000 & 49 & 20,000 & 73 \\
\hline & 14,000 & 104 & 22,000 & 200 \\
\hline & 12,000 & 52 & 22,000 & 80 \\
\hline & 18,000 & 100 & 19,000 & 200 \\
\hline & $\begin{array}{l}\text { Strain } L \\
0 \text { min. }\end{array}$ & $\begin{array}{l}\text { me } A \text { ) } \\
\text { min. }\end{array}$ & $\begin{array}{l}\text { Strain } Q \\
0 \text { min. }\end{array}$ & $\begin{array}{l}\text { ype } A \text { ) } \\
20 \text { min. }\end{array}$ \\
\hline \multirow{4}{*}{$\begin{array}{l}\text { Pork infusion thio- } \\
\text { glycollate agar } p \mathrm{H} 7 \cdot 1 \\
+0 \cdot 1 \% \text { dog } \\
\text { liver glycogen } \\
+0 \cdot 1 \% \text { oyster } \\
\text { glycogen } \\
+0 \cdot 1 \% \text { soluble } \\
\text { starch }\end{array}$} & 25,000 & 1 & 60,000 & 0 \\
\hline & 24,000 & 8 & 60,000 & 5 \\
\hline & 29,000 & 4 & 60,000 & 1 \\
\hline & 23,000 & 76 & 56,000 & 50 \\
\hline
\end{tabular}

to five times as active as the parent starch. It is likely, therefore, that the activity of natural starches resides primarily in the amylose rather than the amylo-pectin fraction.

Although no reason can be advanced for the observed effect of starch in increasing the numbers of spores 'surviving' heat treatment, the phenomenon has been found to apply under a wide range of condition. For spores heated in phosphate buffer, or in vegetable in fusions, the beneflcial effects of additions of starch have been observed in media at various $p$ H levels, at various temperatures of incubation and in agar, gelatine and liquid preparations. The liquid cooked meat medium generally advocated for the detection of heated $\mathrm{Cl}$. botulinum spores frequently fails to detect survivors, whereas as many a hundred spores develop after s similar inoculum is transferred to a suitable solid medium containing starch

Significant responses to the addition of starch have been obtained with heated spores of all strains tested. These include thirteen strain of Cl. botulinum (nine Australian, four American), eight other specie of Clostridium, and ten strains of Bacillus. With the Bacillus strains, all of which were isolated from spoiled canned foods, the magnitude of the response to the addition of starch varies widely between strains and between media.

The results of these experiments will be published in detail elsewhere

Food Preservation Research Laboratory, A. M. OLSEN.
W. J. SCOTT.

Council for Scientiflc and Industrial Research, Homebush, N.S.W. Sept. 25.

1 Brewer, J. H., J. Amer. Med. As80c., 115, 598 (1940). 8 Schoch, T. J., J. Amer. Chem. Soc., 64, 2957 (1942).

\section{Chemistry of Leucaemia}

THE chemical approach to leucæmia has centred mainly on the examination of urines from leucæmic patients. For a long time scarcely any signiflcant differences between normal and leucæmic urines were found ${ }^{1}$. This stagnation has recently been broken by the work of Turner, Miller and their associates ${ }^{2}$ who have shown that human leucwic urines contain substances which, when injected into guinea pigs, induce leucrmic inflitrations in many organs. The active products were extracted with chloroform. Other substances, chemically unrelated to those investigated by Turner, Miller et al. but with the same action on guinea pigs, have been investigated by Parsons ${ }^{3}$. There is no evidence that any one of the compounds studied cause human leucrmia, but the results of Turner and Miller focus interest on the chemical investigation of leucæmic urines as a source of active compounds or of specific metabolites. A preliminary report of further researches in this direction is given in this communication.

Three sharply characterized, apparently new compounds have been isolated from leucæmic urines : (1) a crystalline purple pigment, (2) a yellow pigment, and (3) a colourless, crystalline substance, m.p. 176-177

The purple pigment (1) can be extracted from alkaline solution with ether and removed from the etherial solution by a mixture of water methanol and potassium hydroxide. If the alkaline solution is diluted with water the pigment can again be transferred to ether. It has been possible to characterize this substance by its X-ray powder diagram, but the quantity isolated was not sufficient for microanalyses (Fig. $1, a$ and $b$ ). The purple pigment is always present in leucomic urines. Normal urine seems to contain the same or a similar compound in considerably smaller amounts.

The yellow pigment (2) is found in the benzoic acid fractions. It is characterized by two reactions: $(a)$ the yellow solution of the pigment in ether, when treated with talc and shaken with dilute sodium hydroxide, gives a bright red sodium salt which is soluble in water (b) the pigment can be adsorbed on aluminium oxide from its solution in ether or methanol. It forms a pink compound which can be eluted with dilute alkali giving a red alkali salt. It cannot be eluted with organic solvents. The pigment crystallizes easily at first but loses its resdiness for crystallization on storing or on treating with orgsic solvents in diffuse daylight. 